\title{
Glutathione metabolism and nuclear factor erythroid 2-like 2 (NFE2L2)-related proteins in adipose tissue are altered by supply of ethyl-cellulose rumen-protected methionine in peripartal Holstein cows
}

\author{
Y. Liang, ${ }^{1}$ F. Batistel, ${ }^{2}$ C. Parys,${ }^{3}$ and J. J. Loor ${ }^{1 *}$ \\ ${ }^{1}$ Department of Animal Sciences and Division of Nutritional Sciences, University of Illinois, Urbana 61801 \\ ${ }^{2}$ Department of Animal, Dairy and Veterinary Sciences, Utah State University, Logan 84322 \\ ${ }^{3}$ Evonik Nutrition and Care GmbH, Hanau-Wolfgang, 63457, Germany
}

\section{ABSTRACT}

Enhancing the supply of rumen-protected Met (RPM) during the peripartum period alleviates inflammation and oxidative stress status in dairy cows. We tested the hypothesis that RPM could increase abundance of genes and proteins related to glutathione (GSH) metabolism and the antioxidant transcription factor nuclear factor erythroid 2-like 2 (NFE2L2) in subcutaneous adipose tissue. Multiparous Holstein cows were fed a basal diet [control prepartum diet $=$ $1.47 \mathrm{Mcal} / \mathrm{kg}$ of dry matter (DM) and $15.3 \%$ crude protein; control postpartum diet $=1.67 \mathrm{Mcal} / \mathrm{kg}$ of DM and $17.7 \%$ crude protein] or the control plus ethylcellulose RPM at a rate of 0.09 and $0.10 \%$ of DM intake before expected calving and after calving, respectively. Sixty cows were assigned to treatments based on parity, previous 305-d milk yield, and body condition score at $28 \mathrm{~d}$ from parturition. Diets were fed from -28 to 30 d. Biopsies of subcutaneous adipose tissue collected on $\mathrm{d}-10,10$, and 30 relative to parturition from 7 cows in each group were used for measuring concentrations of GSH, reactive oxygen species, superoxide dismutase, malondialdehyde, and mRNA and protein abundance (Western blotting). A repeated-measures ANOVA was used for statistics. The statistical model included the random effect of block and fixed effects of treatment, time, and its interaction. There was a diet $\times$ time effect for reactive oxygen species due to lower concentrations in Met versus control cows specifically at $d-10$. Cows fed Met also had lower concentrations of malondialdehyde in subcutaneous adipose tissue. Compared with controls, overall mRNA abundance of the GSH metabolism-related genes cystathionine- $\beta$-synthase $(C B S)$, glutamate-cysteine ligase modifier subunit (GCLM), glutathione reductase $(G S R)$, and glutathione peroxi-

Received September 13, 2018.

Accepted February 21, 2019.

*Corresponding author: jloor@illinois.edu dase 1 (GPX1) was greater in cows fed Met. Furthermore, supply of Met resulted in an overall upregulation of protein abundance of glutathione peroxidase (GPX) 1, GPX3, glutathione S-transferase mu 1 (GSTM1), and glutathione S-transferase $\alpha 4$ (GSTA4), all related to GSH metabolism. There was a diet $\times$ time effect for protein abundance of NFE2L2 and its repressor Kelch-like ECH associated protein 1 (KEAP1) due to lower values at $30 \mathrm{~d}$ in cows fed Met versus controls. The abundance of phosphorylated NFE2L2 was lower at $30 \mathrm{~d}$ in response to Met. Overall, the data suggest that exogenous Met may play a role in activating GSH metabolism and the antioxidant NFE2L2 pathways in subcutaneous adipose tissue.

Key words: amino acid, inflammation, lactation, oxidative stress

\section{INTRODUCTION}

During the peripartal period, dairy cows usually experience negative energy balance due to the increased nutrient requirements for fetal growth, milk synthesis, and decreased feed intake (Loor et al., 2013b; Roche et al., 2013). Therefore, mobilization of body fat and skeletal muscle helps cows satisfy the demands for energy. Reactive oxygen species (ROS) concentrations in plasma increase during early lactation, contributing to oxidative stress status (Bernabucci et al., 2005). Production of ROS due to the mobilization of fatty acids, lipotoxicity, and mitochondrial activity (FernándezSánchez et al., 2011) in the adipose tissue contributes to oxidative stress (Furukawa et al., 2004; Li et al., 2015). A pronounced state of oxidative stress could lead to inflammation and immune dysfunction, both of which contribute to metabolic disorders (Du et al., 2018; Zhu et al., 2019). For example, inadequate supply of essential vitamins and trace minerals (e.g., vitamin E or Se) due to decreased DMI around parturition could impair antioxidant synthesis and lower the functionality of circulating leukocytes (Bendich, 1993; Spears, 2000). 
Oxidative stress increases oxylipid production derived from cellular membrane omega-6 fatty acid metabolism and can contribute to inflammation (Loor et al., 2013a; Mavangira and Sordillo, 2018). Therefore, oxidative stress has a negative effect on both production performance and welfare in dairy cows (Loor et al., 2013a).

Glutathione (GSH) is a well-established antioxidant in cells and plays a critical role in the maintenance and regulation of the thiol-redox status (Aquilano et al., 2014). Methionine, which is one of the most-limiting AA for lactating dairy cattle, participates in one-carbon metabolism and synthesis of GSH, both of which occur primarily in the liver (Martinov et al., 2010; Zhou et al., 2016a, 2017). When Lys was adequate, feeding RPM to achieve a Lys:Met ratio close to 2.8:1 in the MP during the periparturient period consistently alleviated oxidative stress status and inflammation in dairy cows and improved DMI and milk yield (Osorio et al., 2014b; Batistel et al., 2017; Zhou et al., 2017). Previous data have provided some indication that adipose may play a role in the induction of oxidative stress (Bernabucci et al., 2005; Contreras et al., 2017). For instance, in nonruminants, adipose tissue can secrete several adipokines that are associated with oxidative stress and inflammation (Shoelson et al., 2006; McGown et al., 2014; Murri et al., 2014). In nonruminants, nuclear factor erythroid 2-like 2 (NFE2L2; formerly Nrf2) is a key transcription factor controlling cellular oxidative stress in part by increasing the mRNA abundance of antioxidant enzymes (Kaspar et al., 2009). In dairy cows, heat stress was associated with greater protein abundance of NFE2L2 in subcutaneous adipose in late pregnancy, indicating that stressors can elicit a tissue-specific antioxidant response (Zachut et al., 2017). Thus, NFE2L2 may play an important role in the subcutaneous adipose tissue during the periparturient period. The objective of the current study was to evaluate changes in mRNA and protein abundance of various components of the GSH synthesis pathway and the NFE2L2 signaling pathway using adipose tissue samples from control and RPM-fed cows in the study of Batistel et al. (2017).

\section{MATERIALS AND METHODS}

\section{Experiment Design and Treatments}

All procedures involving animals were conducted under protocols approved by the University of Illinois Institutional Animal Care and Use Committee (Urbana; protocol no. 14270). Details of the experimental design have been published previously (Batistel et al., 2017). Briefly, 60 multiparous Holstein cows (average lactation number $3.22 \pm 1.11$ ) were assigned to a basal diet (control, $\mathrm{n}=30$ ) without additional Met or the basal diet with ethyl-cellulose RPM (Met, $\mathrm{n}=30$; Mepron, Evonik Nutrition and Care GmbH, Hanau-Wolfgang, Germany) in a randomized complete block design. Mepron contains $85 \%$ DL-Met, and the rumen bypass coefficient of Mepron is $80 \%$ (Overton et al., 1996). The RPM was top dressed from -28 to $60 \mathrm{~d}$ relative to parturition at a rate of 0.09 and $0.10 \%$ of DMI of the previous day before and after calving, respectively, to achieve a Lys:Met ratio of 2.8:1. The basal diet had a Lys:Met ratio of 3.71:1 (prepartum) to 3.78:1 (postpartum). A Lys:Met ratio of 2.8:1 to $2.9: 1$ has proven beneficial for dairy cow production performance and health, including greater DMI and milk yield, better immune function, and lower incidence of ketosis postpartum (Osorio et al., 2013; Zhou et al., 2016b). From -45 to -29 d relative to calving date, all cows were fed the same diet without RPM. Diets were mixed daily using a TMR truck with horizontal rotors and fed once daily $(1300 \mathrm{~h})$. The cows were milked daily at 0600 , 1400, and $2200 \mathrm{~h}$. The ingredient and chemical composition of the diets was published previously (Batistel et al., 2017). Diets were formulated to meet predicted requirements for dairy cows according to NRC (2001).

\section{Adipose Tissue Biopsies}

A subset of 7 cows in the control or Met groups was used for adipose biopsies. These cows were selected based on actual days receiving diets prepartum (28 \pm $3 \mathrm{~d}$ ) and absence of clinical disorders, and all had a full set of biopsies. These cows did not receive any veterinary treatment. Furthermore, they averaged 21,420 to $22,062 \mathrm{~kg}$ of milk in the previous 305 -d lactation and had a BCS of 3.5 to 3.7 at treatment assignment. Tissue was harvested from the tail head (alternating between the right and left tail head region) at $-10( \pm 3$ d), 10, and $30 \mathrm{~d}$ relative to parturition according to previous procedures from our laboratory (Ji et al., 2012). Upon collection, adipose tissue was immediately placed in screw-capped microcentrifuge tubes, snap frozen in liquid nitrogen, and preserved at $-80^{\circ} \mathrm{C}$ until further analysis. Health was monitored for $7 \mathrm{~d}$ after surgery. Surgical clips were removed after $7 \mathrm{~d}$ postbiopsy. Cows were the last to be milked and returned to their tiestalls after the $0400 \mathrm{~h}$ milking. They did not have access to feed before biopsy, all of which were completed at approximately $0800 \mathrm{~h}$. No antibiotics were administered postbiopsy.

\section{RNA Isolation, cDNA Synthesis, and Quantitative PCR}

Total RNA was isolated from $200 \mathrm{mg}$ of adipose tissue using the miRNeasy kit (Qiagen, Hilden, Germany) 
according to the manufacturer's protocols. The RNA samples were digested with DNaseI, and quantification was assessed using a NanoDrop ND-1000 spectrophotometer (Thermo Fisher Scientific, Waltham, MA). The quality of RNA samples was measured using an Agilent 2100 Bioanalyzer (Agilent Technologies, Santa Clara, CA). Quantitative PCR was performed as described previously (Osorio et al., 2014b). Previously validated internal controls for adipose tissue were ribosomal protein S9 (RPS9), GAPDH, and actin $\beta$ ( $A C T B$; Vailati Riboni et al., 2015, 2016, 2017). A comprehensive literature search was conducted to select NFE2L2 and GSH metabolism target genes and regulators that play crucial roles in cellular antioxidant mechanisms (Motohashi and Yamamoto, 2004; Stipanuk, 2004; Lu, 2009). Gene symbols and names, quantitative PCR performance, and primer information are presented in Supplemental Table S1 (https://doi.org/10.3168/jds .2018-15687).

\section{Western Blot Analysis}

Total protein was extracted from $100 \mathrm{mg}$ of adipose tissue using a tissue protein extraction reagent (catalog no. 78510; Thermo Fisher Scientific) containing Halt protease and phosphatase inhibitor cocktail (100×, catalog no. 78442; Thermo Fisher Scientific). The concentration of total protein was determined using a NanoDrop ND-1000 (Thermo Fisher Scientific). Protein samples were denatured by heating at $100^{\circ} \mathrm{C}$ for $5 \mathrm{~min}$ before loading $75 \mu \mathrm{g}$ of protein into each lane of a 4-20\% SDS-PAGE gel (catalog no. 4561096; Bio-Rad, Hercules, CA). Reactions were run for $10 \mathrm{~min}$ at $180 \mathrm{~V}$, and then for 45 to $60 \mathrm{~min}$ at $110 \mathrm{~V}$. After activating a polyvinylidene fluoride membrane (catalog no. 1620261; Bio-Rad) with methanol for $1 \mathrm{~min}$, the protein sample was transferred to the membrane in a Trans-Blot SD Semi-Dry Electrophoretic Transfer Cell (catalog no. 170-3940; Bio-Rad). Membranes were then blocked in $1 \times$ Tris-buffered saline (TBST) containing $5 \%$ nonfat milk for $2 \mathrm{~h}$ at room temperature. The membranes were then incubated in $1 \times$ TBST containing primary antibodies to hydroxycarboxylic acid receptor 2 (HCAR2), glutathione peroxidase (GPX) 1, GPX3, glutathione S-transferase mu 1 (GSTM1), glutathione S-transferase $\alpha 4$ (GSTA4), Kelch-like ECH associated protein 1 (KEAP1), heme oxygenase 1 (HMOX1), mitogen-activated protein kinase 3 (ERK1), phosphoERK1 (Thr202), NFE2L2, and phospho-NFE2L2 (Ser40); catalog number and dilution ratio are included in Supplemental Table S2 (https://doi.org/10.3168/jds $.2018-15687$ ) overnight at $4^{\circ} \mathrm{C}$. The membranes were then washed 6 times with $1 \times$ TBST and incubated with anti-rabbit horseradish peroxidase-conjugated secondary antibodies (catalog no. 7074S; dilution 1:3,000; Cell Signaling Technology, Danvers, MA) for $1 \mathrm{~h}$ at room temperature. Subsequently, the membranes were washed 6 times with $1 \times$ TBST and then incubated with enhanced chemiluminescence reagent (catalog no. 170-5060; Bio-Rad) for 3 min in the dark prior to image acquisition. Actin- $\beta$ (catalog no. 4967S; Cell Signaling Technology) was used as the internal control. Images were acquired using the ChemiDOC MP Imaging System (Bio-Rad). The intensities of the bands were measured with Image-Pro Plus 6.0 software (Media Cybernetics, Rockville, MD). Specific target protein band density values were normalized to $\beta$-actin density values. Representative blots are included in Supplemental Figure S1 (https://doi.org/10.3168/jds.2018-15687).

\section{Oxidative Stress Analysis in Subcutaneous Adipose Tissue}

Superoxide dismutase (catalog no. 706002; Cayman Chemical, Ann Arbor, MI), malondialdehyde (MDA; catalog no. 10009055; Cayman Chemical), GSH (catalog no. NWK-GSH01; Northwest Life Science Specialties, Vancouver, WA), and ROS (catalog no. STA-347, Cell Biolabs, San Diego, CA) were analyzed in subcutaneous adipose tissue using commercial kits. Concentration of total protein of the adipose samples was measured using the BCA assay kit (catalog no. 23227; Thermo Fisher Scientific).

\section{Statistical Analysis}

The data were analyzed using the MIXED procedure of SAS version 9.4 (SAS Institute Inc., Cary, NC) according to the following model with repeated measures:

$$
\mathrm{Y}_{\mathrm{j} 1}=\mu+\mathrm{M}_{\mathrm{j}}+\mathrm{T}_{1}+\mathrm{MT}_{\mathrm{j} 1}+\mathrm{e}_{\mathrm{jl}},
$$

where $Y_{j 1}=$ dependent continuous variable, $\mu=$ overall mean, $M_{j}=$ fixed effect of $\operatorname{diet}(\mathrm{j}=$ control vs. Met $)$, $\mathrm{T}_{1}=$ fixed effect of day $(-10,10$, and $30 \mathrm{~d}), \mathrm{MT}_{\mathrm{jl}}=$ interaction between diet and day, and $\mathrm{e}_{\mathrm{jl}}=$ residual error. Cow nested within treatment was the random effect. The Kenward-Roger statement was used for computing the denominator degrees of freedom. The covariance structure of the repeated measurements was spatial power. When the interaction was significant, least squares means separation between and within time points was performed using the PDIFF statement with Tukey adjustment. Normality of the residuals was checked with normal probability and box plots, and homogeneity of variances was checked with plots 
of residuals versus predicted values. Significance was determined at $P \leq 0.05$ and tendencies at $P \leq 0.10$.

\section{RESULTS}

\section{NFE2L2 Target Gene Abundance}

Main effects of diet, day, and interactions are reported in Figures 1, 2, and 3. The diet $\times$ day effect was not significant $(P>0.05)$ for any gene measured. Abundance of NFE2L2 $(P=0.06$; Figure 1$)$ and $C B S$ $(P=0.06$; Figure 2$)$ tended to be greater in response to enhanced Met supply. In addition, enhanced Met supply led to greater overall mRNA abundance (Figure 3) of $\operatorname{GCLM}(P=0.03), \operatorname{GSR}(P=0.02)$, TALDO1 $(P$ $=0.04)$, and $M E 1(P=0.04)$.

\section{Protein Abundance}

Main effects of diet, day, and interactions are reported in Figures 4, 5, and 6. The diet $\times$ day interaction was significant for protein abundance of NFE2L2 $(P=0.05)$ and KEAP1 $(P<0.01)$, namely due to lower abundance of NFE2L2 $(P<0.01)$ at $10 \mathrm{~d}$ and greater abundance of KEAP1 at $30 \mathrm{~d}$ in Met compared with control cows (Figure 4). Although abundance of phosphorylated (p)-NFE2L2 could not be detected at -10 and $10 \mathrm{~d}$ in both control and Met cows, at $30 \mathrm{~d}$ postpartum abundance of p-NFE2L2 $(P<0.05)$ was lower in Met cows compared with controls (Figure 4). However, there was no difference in p-NFE2L2:NFE2L2 ratio between Met cows and the controls. Compared with controls, cows fed Met had lower abundance of the NFE2L2 target HMOX1 $(P<0.05)$.

Among the enzymes associated with GSH metabolism, enhancing the supply of Met resulted in an overall upregulation $(P<0.05)$ of GPX1, GPX3, GSTM1, and GSTA4 $(P<0.05$; Figure 5$)$. The diet $\times$ day interaction tended to be significant $(P=0.06)$ for p-ERK1 due to Met cows having greater $(P<0.01)$ abundance at $10 \mathrm{~d}$ compared with controls (Figure 6 ). In addition, p-ERK1 tended to be greater $(P=0.06)$ in Met compared with control cows at $30 \mathrm{~d}$. Overall abundance of HCAR2 and ERK1 in response to enhancing Met supply was greater $(P<0.05$; Figure 6$)$. The ratio of p-ERK1 to total ERK1 was greater $(P<0.01)$ in cows fed Met compared with controls due to greater $(P<$ $0.05)$ values at $d 10$.

\section{Oxidative Stress in Subcutaneous Adipose Tissue}

The main effects of diet, time, and interactions are reported in Figure 7 . The diet $\times$ day interaction was

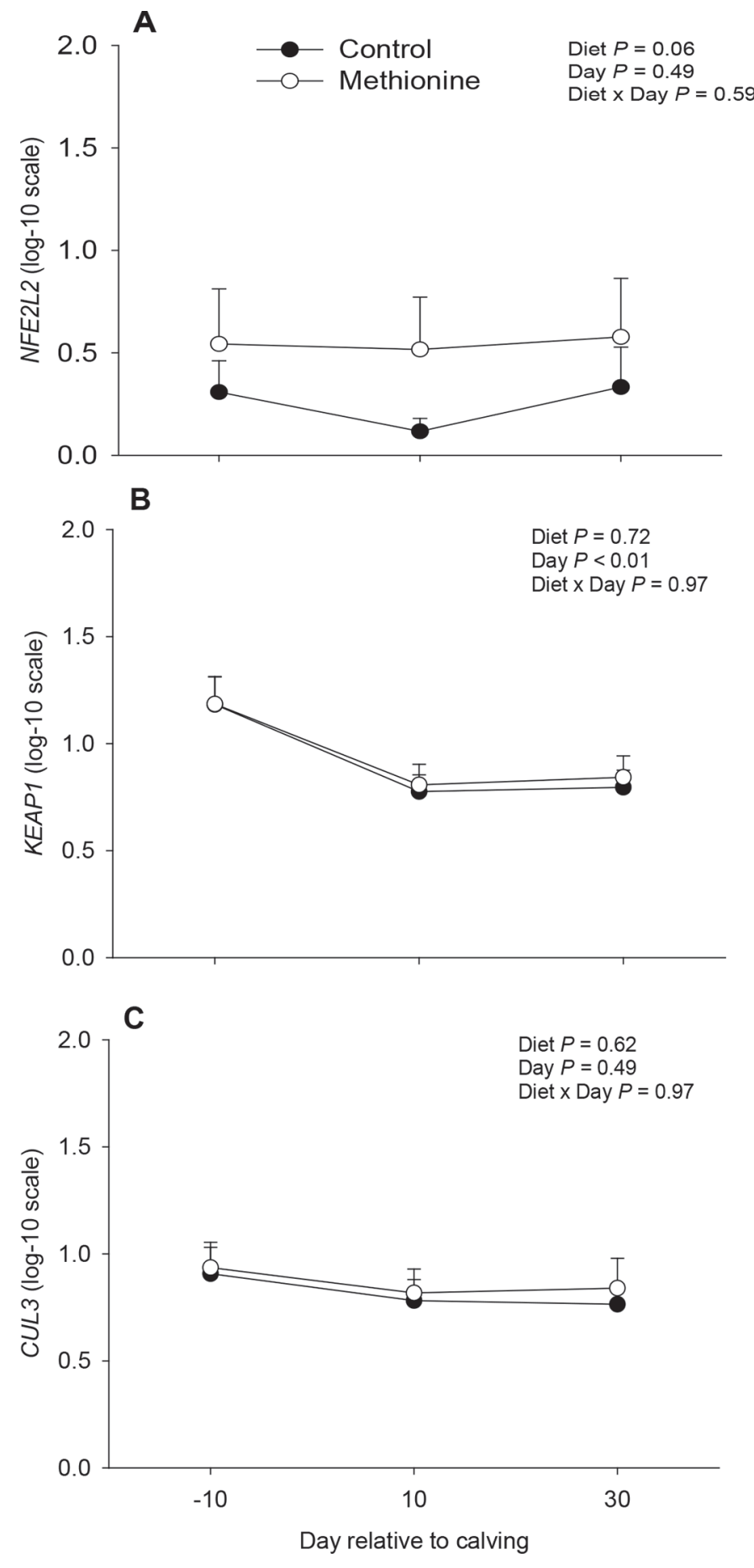

Figure 1. Messenger RNA abundance (log-10 scale) of the antioxidant transcription factor NFE2L2 (A) and the NFE2L2 repressors $K E A P 1(\mathrm{~B})$ and $C U L 3(\mathrm{C})$ in subcutaneous adipose tissue harvested at $-10,10$, and $30 \mathrm{~d}$ relative to parturition. Holstein cows were fed a basal diet (control prepartum diet: $1.47 \mathrm{Mcal} / \mathrm{kg}$ of DM and $15.3 \%$ $\mathrm{CP}$; control postpartum diet: $1.67 \mathrm{Mcal} / \mathrm{kg}$ of $\mathrm{DM}$ and $17.7 \% \mathrm{CP}$ ) or the control plus ethyl-cellulose rumen-protected Met at a rate of 0.09 and $0.10 \%$ of DMI from $-28 \mathrm{~d}$ to calving and from 1 through $30 \mathrm{~d}$ postcalving, respectively. Data are LSM \pm pooled SEM, $\mathrm{n}=7$ cows/ diet. $N F E 2 L 2=$ nuclear factor erythroid 2-like 2; KEAP1 $=$ Kelch-like ECH associated protein $1 ; C U L 3=$ cullin 3 . 

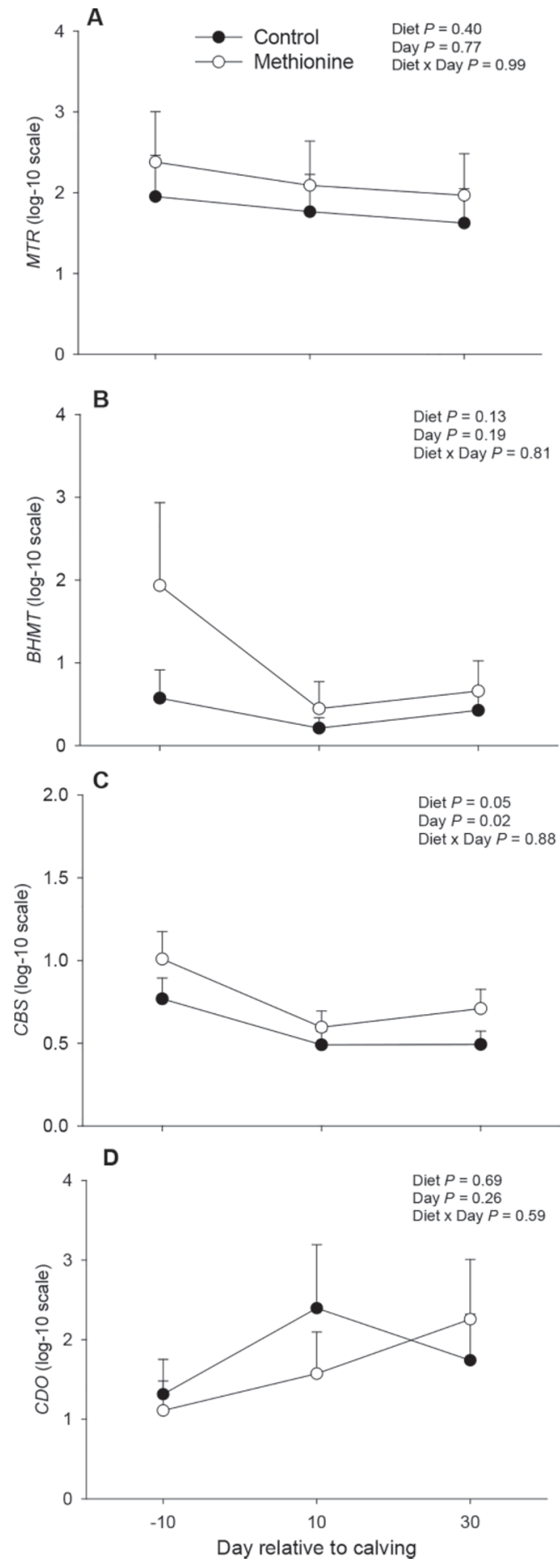

Figure 2. Messenger RNA abundance (log-10 scale) of the onecarbon metabolism-related genes $M T R(\mathrm{~A}), B H M T(\mathrm{~B}), C B S(\mathrm{C})$, and $C D O(\mathrm{D})$ in subcutaneous adipose tissue harvested at $-10,10$, and $30 \mathrm{~d}$ relative to parturition. Holstein cows were fed a basal diet (control prepartum diet: $1.47 \mathrm{Mcal} / \mathrm{kg}$ of $\mathrm{DM}$ and $15.3 \% \mathrm{CP}$; control postpartum diet: $1.67 \mathrm{Mcal} / \mathrm{kg}$ of DM and $17.7 \% \mathrm{CP}$ ) or the control plus ethyl-cellulose rumen-protected Met at a rate of 0.09 and $0.10 \%$ of DMI from $-28 \mathrm{~d}$ to calving and from 1 through $30 \mathrm{~d}$ postcalving, respectively. Data are LSM \pm pooled SEM, $\mathrm{n}=7$ cows/diet. $M T R=$ methionine synthase; $B H M T=$ betaine homocysteine methyltransferase; $C B S=$ cystathionine $\beta$-synthase $C D O=$ cysteine dioxygenase. significant for ROS $(P<0.05)$, namely due to a lower concentration $(P<0.05)$ at $-10 \mathrm{~d}$ in Met compared with control cows (Figure 7). The concentration of MDA was lower $(P<0.05)$ overall in Met cows.

\section{DISCUSSION}

At a mechanistic level, changes in mRNA abundance associated with GSH metabolism and the NFE2L2 pathway in the liver and mammary gland tissue contribute to the reduction in oxidative stress in dairy cows receiving enhanced postruminal supply of Met (Osorio et al., 2014a; Han et al., 2018a). Furthermore, enhanced supply of Met increased the phosphorylation status of NFE2L2 in the mammary gland (Han et al., 2018a). In the current study, the potential benefit of Met in the subcutaneous adipose tissue antioxidant response is likely part of the overall benefits observed in alleviation of inflammation and oxidative stress in the same group of cows.

\section{Oxidative Stress Biomarkers and mRNA Abundance of Genes in the One-Carbon and GSH Metabolism Pathways in Adipose Tissue}

The concentration of ROS is a well-established biomarker for oxidative stress. The lower plasma ROS concentration detected in the entire cohort of cows (Batistel et al., 2017, 2018) used in this study agreed with previous data indicating a lower oxidative stress status (Osorio et al., 2014a; Zhou et al., 2016b, 2017). Although we did not attempt to quantify Met content in subcutaneous adipose, the lower concentration of MDA (measure of peroxides derived from PUFA) in cows fed Met suggests a less pronounced state of oxidative stress, which is consistent with plasma data from the bigger cohort of cows in this study (Batistel et al., 2018). Because nonspecific products of lipid peroxidation could interfere with the MDA assay, additional research is needed to confirm whether nutrients or stressors alter oxidative status in bovine adipose tissue.

Glutathione, one of the major antioxidants in the cell, helps prevent damage caused by ROS (Yu, 1994). At least in nonruminants, Cys availability limits GSH biosynthesis (Griffith, 1999). Methionine can be converted to Cys by the transsulfuration pathway, with the enzyme CBS being rate limiting (Kane et al., 1990). The greater overall mRNA abundance of $C B S$ coupled with greater DMI (Batistel et al., 2017) in Met-fed cows could be taken as an indication that adipocytes had greater biosynthesis of cystathionine, Cys, and eventually GSH. Besides greater availability of Met in response to greater DMI, cows fed Met also would have had increased intakes of trace minerals 

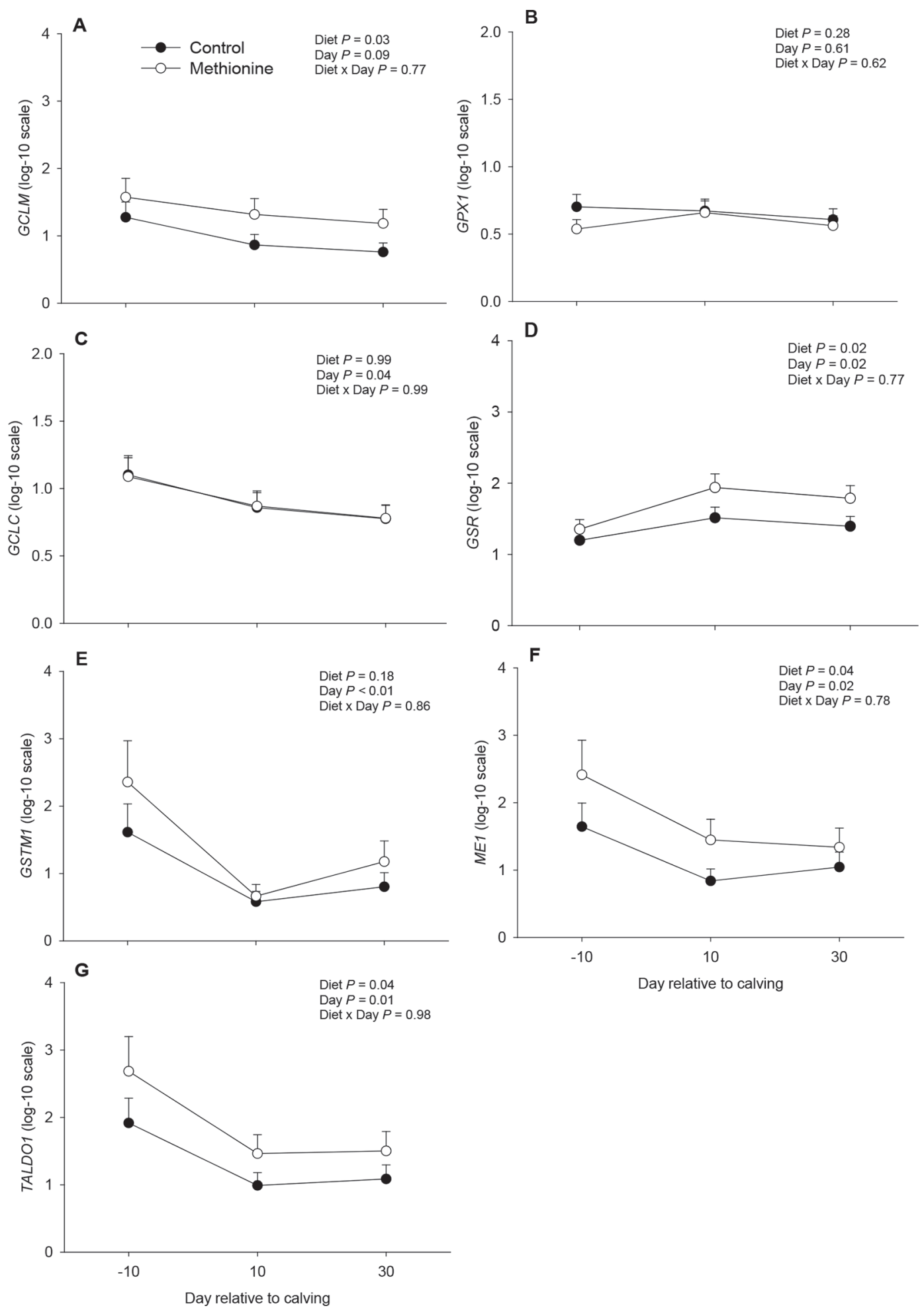

Figure 3. Messenger RNA abundance (log-10 scale) of the glutathione metabolism-associated genes $G C L M(\mathrm{~A}), G P X 1$ (B), GCLC (C), GSR (D), GSTM1 (E), ME1 (F), and TALDO1 (G) in subcutaneous adipose tissue harvested at $-10,10$, and 30 d relative to parturition. Holstein cows were fed a basal diet (control prepartum diet: $1.47 \mathrm{Mcal} / \mathrm{kg}$ of DM and $15.3 \% \mathrm{CP}$; control postpartum diet: $1.67 \mathrm{Mcal} / \mathrm{kg}$ of DM and $17.7 \%$ $\mathrm{CP}$ ) or the control plus ethyl-cellulose rumen-protected Met at a rate of 0.09 and $0.10 \%$ of DMI from $-28 \mathrm{~d}$ to calving and from 1 through 30 d postcalving, respectively. Data are LSM \pm pooled SEM, $\mathrm{n}=7$ cows/diet. $G C L M=$ glutamate-cysteine ligase modifier subunit; GPX1 = glutathione peroxidase 1; $G C L C=$ glutamate-cysteine ligase catalytic subunit; GSR = glutathione reductase; GSTM1 = glutathione S-transferase M1; $M E 1=$ malic enzyme $1 ; T A L D O 1=$ transaldolase 1. 

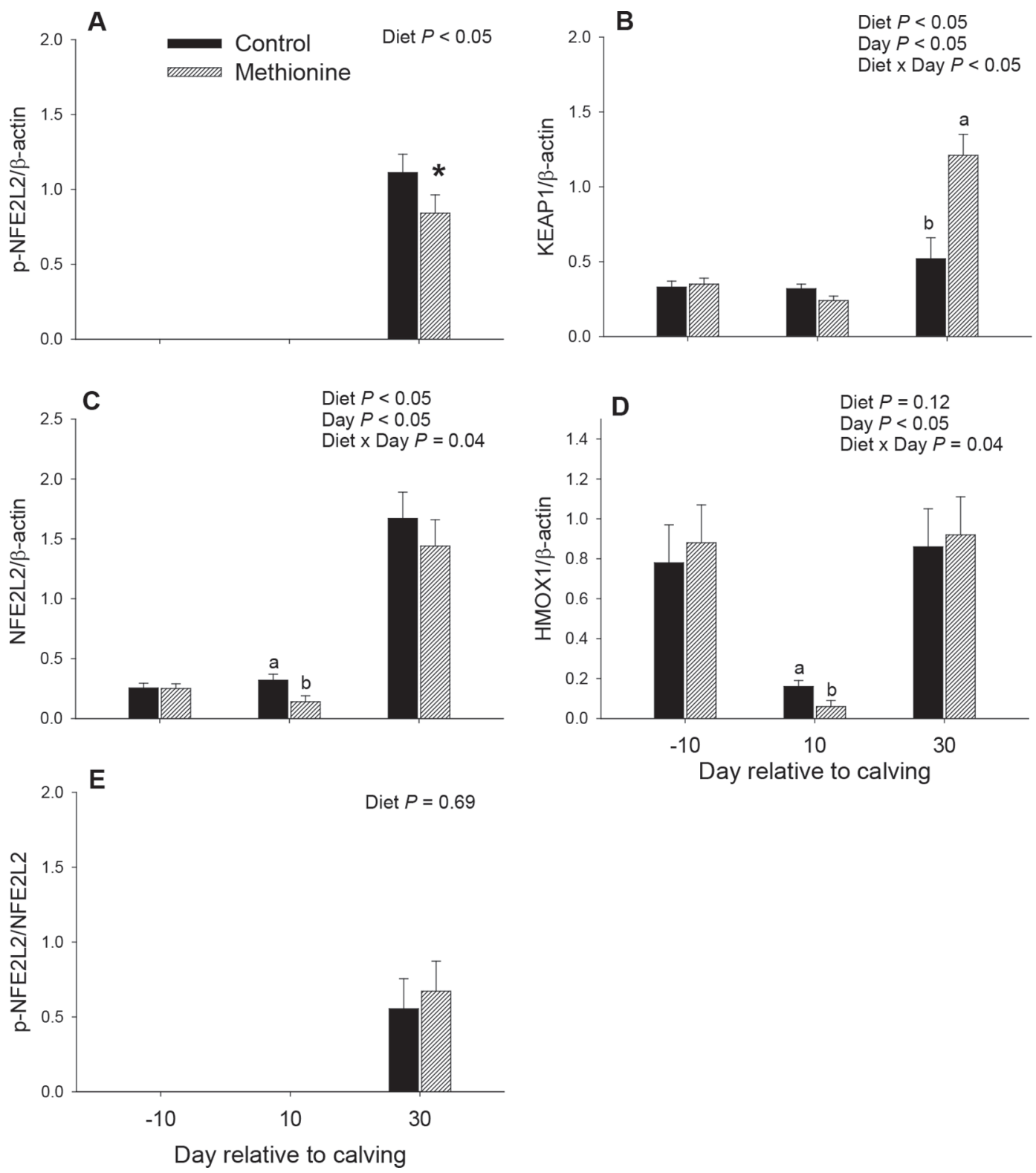

Day relative to calving

Figure 4. Protein abundance (relative to $\beta$-actin) of the antioxidant transcription factor phosphorylated (p)-NFE2L2 (active; A), NFE2L2 repressor KEAP1 (B), NFE2L2 (inactive; C), NFE2L2 target HMOX1 (D), and the p-NFE2L2/NFE2L2 ratio (E) in subcutaneous adipose tissue harvested at $-10,10$, and $30 \mathrm{~d}$ relative to parturition. Holstein cows were fed a basal diet (control prepartum diet: $1.47 \mathrm{Mcal} / \mathrm{kg}$ of DM and $15.3 \% \mathrm{CP}$; control postpartum diet: $1.67 \mathrm{Mcal} / \mathrm{kg}$ of DM and $17.7 \% \mathrm{CP}$ ) or the control plus ethyl-cellulose rumen-protected Met at a rate of 0.09 and $0.10 \%$ of DMI from $-28 \mathrm{~d}$ to calving and from 1 through $30 \mathrm{~d}$ postcalving, respectively. Data are LSM \pm pooled SEM, $\mathrm{n}=7$ cows/ diet. Abundance of p-NFE2L2 was detectable only at $30 \mathrm{~d}$ postpartum. NFE2L2 = nuclear factor erythroid 2-like 2; KEAP1 = Kelch-like ECH associated protein 1 ; HMOX1 $=$ heme oxygenase 1 . Means with different letters $(\mathrm{a}, \mathrm{b})$ differ (diet $\times$ day, $P \leq 0.05)$. ${ }^{*}$ Means between control and Met differ $(P \leq 0.05)$.

(e.g., Se) and vitamins with roles as antioxidants; for example, concentrations of $\beta$-carotene and tocopherol were greater in plasma from Met-fed cows (Batistel et al., 2018). Further in vitro studies with bovine primary adipocytes, for example, can be designed to measure mRNA and protein abundance, concentrations of ROS, and other intermediates related to GSH metabolism in relation to supply of Met or antioxidants such as Se, $\beta$-carotene, and tocopherol. Such studies would be helpful for better understanding the role of nutrients in the antioxidant response of adipose tissue.

Glutathione reductase is an essential enzyme that converts oxidized GSH to the reduced form (Couto et al., 2016). The enzymes glutamate-cysteine ligase catalytic subunit (GCLC) and glutamate-cysteine ligase modifier subunit (GCLM) are rate limiting for GSH 
metabolism. Malic enzyme 1, a multifunctional protein linking the glycolytic and citric acid cycles, is important for NADPH production (Wen et al., 2015; Nakashima et al., 2018). The enzyme transaldolase 1 (TALDO1) participates in the pentose phosphate pathway and helps provide cells with NADPH, an important redox cofactor (Samland and Sprenger, 2009) known for its role in mitigating oxidative stress. Thus, the upregulation of GSH metabolism genes (GCLM, GSR, ME1, and TALDO1) in response to enhanced postruminal supply of Met indicates that this AA, either directly or via its positive effect on DMI, plays a role in helping adipose tissue alleviate oxidative stress during the transition period.

\section{Abundance of Proteins Associated with GSH Metabolism and NFE2L2}

The enzymes GSTM1, GSTA4, GPX1, and GPX3 play key roles in inactivating pro-oxidant products such as $\mathrm{H}_{2} \mathrm{O}_{2}$ and oxygen radicals in various tissues, including adipose (Lee et al., 2008; Curtis et al., 2010). For instance, GPX3 (a selenium-dependent enzyme; $\mathrm{Yu}$ et al., 2007) and GSTA4 in nonruminant adipose tissue are essential for preventing oxidative stress in conditions associated with excessive fat deposition (Lee et al., 2008). Downregulation of GSTA4 in murine adipocytes resulted in increased ROS production along with lipolysis and reduced glucose uptake (Curtis et al., 2010). The GPX enzymes are oxidized by $\mathrm{H}_{2} \mathrm{O}_{2}$ and reduced by GSH (Sena and Chandel, 2012). Both GSTM1 and GSTA4 belong to the glutathione-S-transferase enzymes that are generally considered to be important for detoxification of electrophiles via GSH conjugation (Strange et al., 2001). Overall, protein abundance of GSH-related protein targets was consistent with mRNA abundance data. The upregulation of protein abundance of GPX1, GPX3, GSTM1, and GSTA4 in response to enhanced Met supply underscores not only that adipose tissue has antioxidant mechanisms related
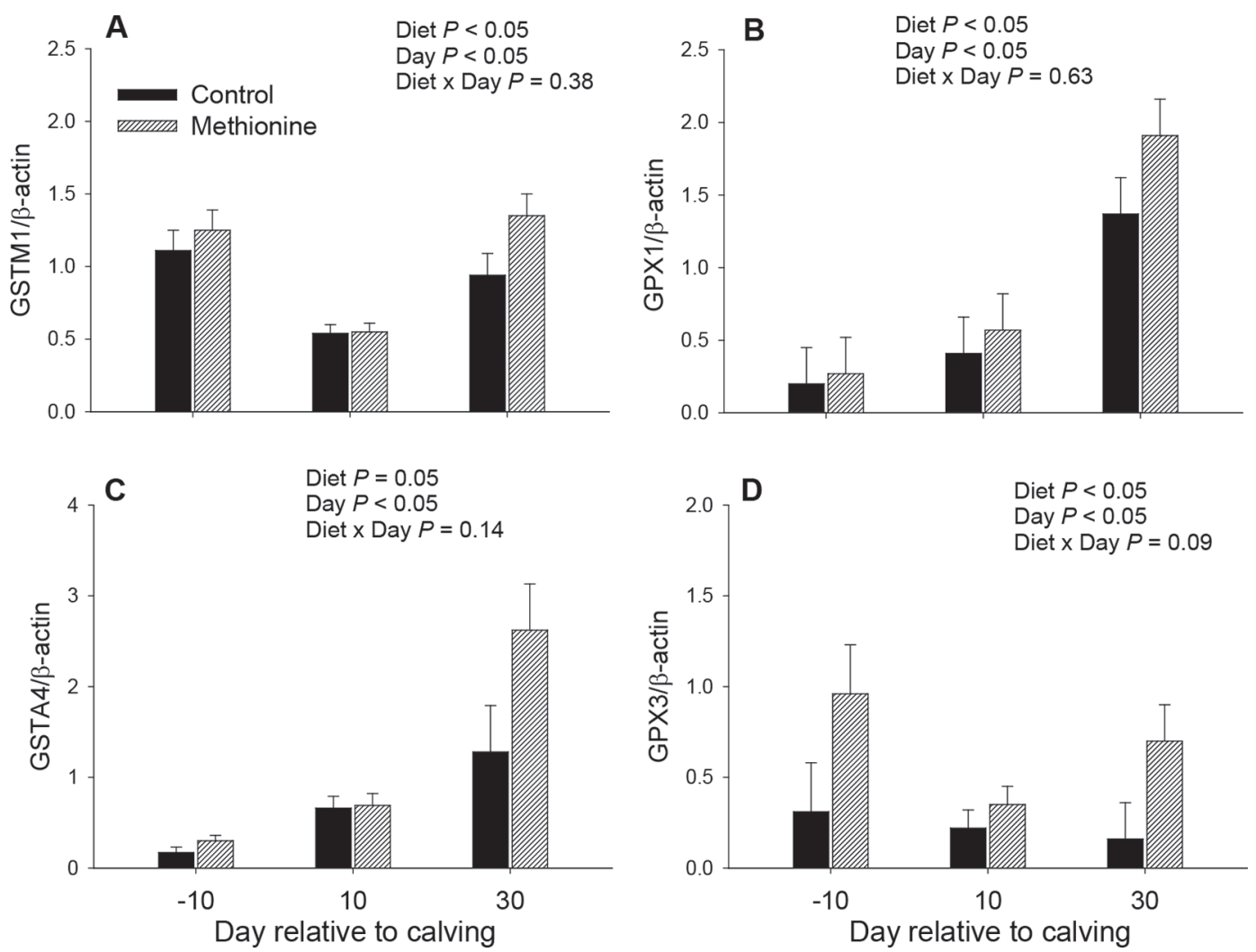

Figure 5. Protein abundance (relative to $\beta$-actin) of the glutathione metabolism-related enzymes GSTM1 (A), GPX1 (B), GSTA4 (C), and GPX3 (D) in subcutaneous adipose tissue harvested at $-10,10$, and $30 \mathrm{~d}$ relative to parturition. Holstein cows were fed a basal diet (control prepartum diet: $1.47 \mathrm{Mcal} / \mathrm{kg}$ of DM and $15.3 \% \mathrm{CP}$; control postpartum diet: $1.67 \mathrm{Mcal} / \mathrm{kg}$ of DM and $17.7 \% \mathrm{CP}$ ) or the control plus ethylcellulose rumen-protected Met at a rate of 0.09 and $0.10 \%$ of DMI from $-28 \mathrm{~d}$ to calving and from 1 through $30 \mathrm{~d}$ postcalving, respectively. Data are LSM \pm pooled SEM, $\mathrm{n}=7$ cows/diet. GSTM1 = glutathione S-transferase mu 1; GPX1 = glutathione peroxidase 1; GPX3 = glutathione peroxidase 3; GSTA4 = glutathione S-transferase $\alpha 4$. 

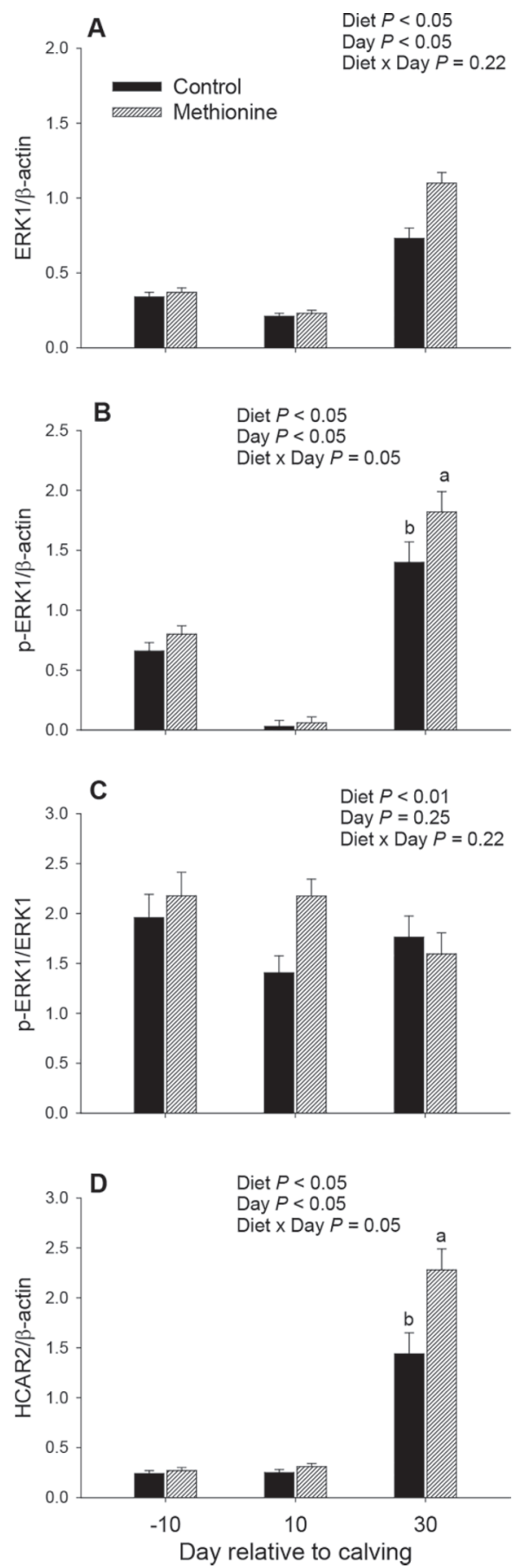

Figure 6. Protein abundance (relative to $\beta$-actin) of the oxidative stress-sensitive protein ERK1 (inactive; A), phosphorylated (p)-ERK1 (active; B), p-ERK1:ERK1 ratio (C), and the inflammation-related G-coupled protein receptor HCAR2 (D) in subcutaneous adipose tissue harvested at $-10,10$, and $30 \mathrm{~d}$ relative to parturition. Holstein cows were fed a basal diet (control prepartum diet: $1.47 \mathrm{Mcal} / \mathrm{kg}$ of $\mathrm{DM}$ and $15.3 \% \mathrm{CP}$; control postpartum diet: $1.67 \mathrm{Mcal} / \mathrm{kg}$ of DM and $17.7 \% \mathrm{CP}$ ) or the control plus ethyl-cellulose rumen-protected Met at a rate of 0.09 and $0.10 \%$ of DMI from $-28 \mathrm{~d}$ to calving and from 1 through $30 \mathrm{~d}$ postcalving, respectively. Data are LSM \pm pooled SEM, $\mathrm{n}=7$ cows/diet. ERK1 = mitogen-activated protein kinase $3 ;$ HCAR2 $=$ hydroxycarboxylic acid receptor 2 . Means with different letters (a, b) differ (diet $\times$ day, $P \leq 0.05$ ).
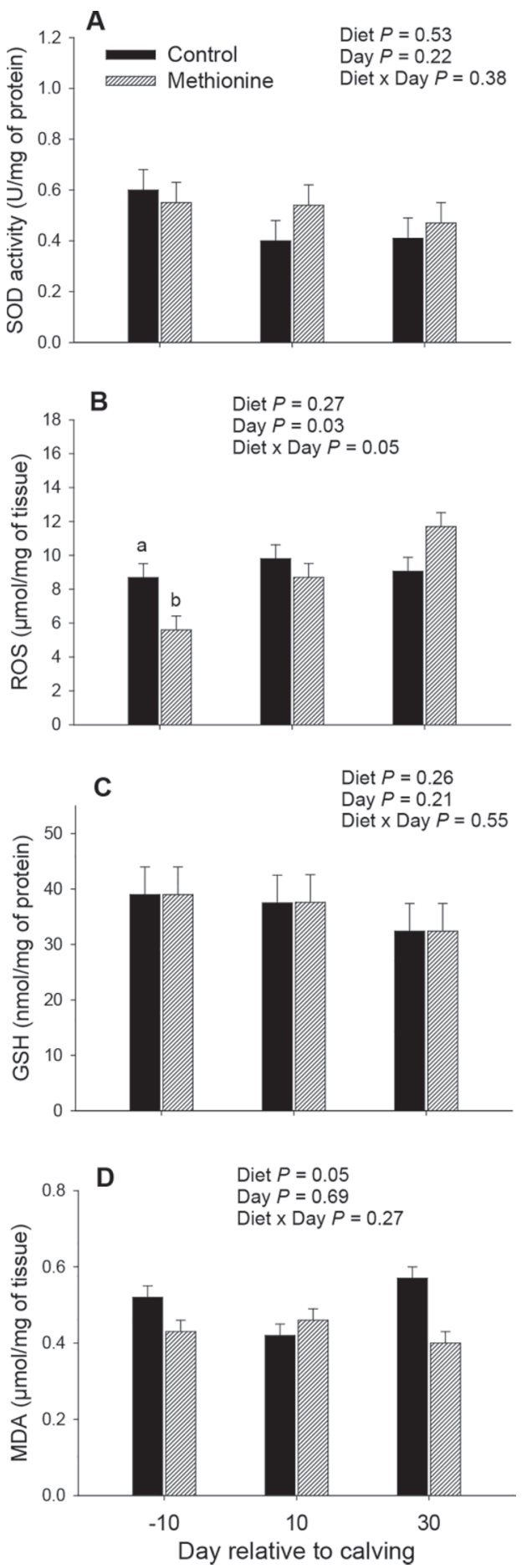

Figure 7. Activity of superoxide dismutase (SOD; A) and concentrations of reactive oxygen species (ROS; B), glutathione (GSH $\mathrm{C}$ ), and malondialdehyde (MDA; D) in subcutaneous adipose tissue harvested at $-10,10$, and $30 \mathrm{~d}$ relative to parturition. Holstein cows were fed a basal diet (control prepartum diet: $1.47 \mathrm{Mcal} / \mathrm{kg}$ of DM and $15.3 \% \mathrm{CP}$; control postpartum diet: $1.67 \mathrm{Mcal} / \mathrm{kg}$ of DM and $17.7 \%$ $\mathrm{CP}$ ) or the control plus ethyl-cellulose rumen-protected Met at a rate of 0.09 and $0.10 \%$ of DMI from $-28 \mathrm{~d}$ to calving and from 1 through $30 \mathrm{~d}$ postcalving, respectively. Data are LSM \pm pooled SEM, $\mathrm{n}=7$ cows/diet. Means with different letters $(\mathrm{a}, \mathrm{b})$ differ (diet $\times$ day, $P \leq$ $0.05)$. 
to GSH but also that these are responsive to greater Met supply or DMI.

The transcription factor NFE2L2 represents a major mechanism for cells to defend against oxidative stress. Expression of the gene was first reported in the transition cow liver (Loor, 2010), and more recent research provided some evidence that it can play an important role during the transition period and late pregnancy (Gessner et al., 2013; Zachut et al., 2017). Therefore, it seems that NFE2L2 plays an important role in the adipose tissue adaptations to the onset of lactation in dairy cows. Most dairy cows mobilize body fat to aid in meeting energy demands for milk synthesis during the transition period, and in that process oxidation of fatty acids also generates ROS (Loor et al., 2013a,b; Roche et al., 2013). Both nutrients and ROS can activate the NFE2L2 pathway (Nguyen et al., 2009; Cardozo et al., 2013), which triggers adaptations in the abundance of KEAP1 (Ade et al., 2009). In the cytosol, KEAP1 binds to NFE2L2, which inhibits its release and promotes proteasomal degradation (Kensler et al., 2007).

The fact that p-NEF2L2 was detectable only at 30 $\mathrm{d}$ postpartum agrees with other data indicating that oxidative stress status increases gradually after calving (Abuelo et al., 2013). In the entire cohort of cows (Batistel et al., 2018), we detected not only a temporal increase in concentration of ROS in plasma but also greater overall values in control cows compared with Met-fed cows. This may partly explain the fact that p-NFE2L2 was not detectable at -10 and $10 \mathrm{~d}$ relative to parturition. Along with mammary tissue data demonstrating a marked upregulation in abundance of p-NFE2L2:total NFE2L2 at $30 \mathrm{~d}$ versus $-30 \mathrm{~d}$ around parturition (Han et al., 2018b), these temporal responses underscore the potential role of NFE2L2 signaling in the defense mechanisms of mammary gland and adipose tissue against oxidative stress.

Taking into account the lower p-NFE2L2 at 30 $\mathrm{d}$ in cows fed Met and the similar p-NFE2L2:total NFE2L2 ratio in the present study along with previous data in which enhanced Met supply upregulated the phosphorylation status of NFE2L2 in the bovine mammary gland (Han et al., 2018a), it seems plausible that this transcription factor is less responsive to Met or less susceptible to ROS in adipose than mammary tissue. Although the greater abundance of KEAP1 at $30 \mathrm{~d}$ in cows fed Met may partly explain the lower p-NFE2L2, the lack of difference in ROS concentration between groups coupled with greater overall abundance of GSTM1, GPX1, GSTA4, and GPX3 in response to Met suggests that this AA helps control tissue ROS independent of NFE2L2.

\section{Protein Abundance of Targets Associated with Response to Inflammation}

It has been proposed that uncontrolled adipose tissue inflammation could intensify lipolysis (Contreras et al., 2018). Hydroxycarboxylic acid receptor 2 belongs to the $\mathrm{G}$ protein-coupled receptor family, and in nonruminants it can serve both an antilipolytic (Offermanns et al., 2011) and anti-inflammatory (Graff et al., 2016) role. Previous work demonstrated wide expression of HCAR2 in bovine tissues, including adipose (Titgemeyer et al., 2011). In addition, there is an indication that enhancing the postruminal supply of nicotinic acid (an agonist of HCAR2) can signal through this receptor and reduce plasma free fatty acid concentrations (Morey et al., 2011; Yuan et al., 2012). Thus, the greater abundance of HCAR2 in response to enhanced Met supply might have served a dual role as in nonruminants (i.e., help control lipolysis as well as inflammation).

Previous research has clearly demonstrated that bovine adipose tissue undergoes an inflammatory response around parturition, which likely affects the antioxidant defense system of the tissue (Vailati Riboni et al., 2015, $2016,2017)$. Oxidative stress is known to cause apoptosis in various cell types, and oxidative damage-induced apoptosis is partly mediated by ERK1/2 phosphorylation (Lee et al., 2003; Du et al., 2017). Thus, the greater phosphorylation status of ERK1 in response to enhanced Met supply was indicative that adipocyte survival might have been sustained in those cows.

\section{CONCLUSIONS}

Several components of the GSH metabolism and NFE2L2 antioxidant signaling pathways are expressed in subcutaneous adipose tissue and respond to the change in physiological state from late pregnancy to early lactation. The gradual increase in protein abundance of key components of these pathways reflects the state of oxidative stress experienced by cows. Supplementation of Met was associated with lower MDA and higher activity of the GSH antioxidant enzymes. Further in vitro studies using adipocytes may help us better understand the role and mechanisms for these responses.

\section{ACKNOWLEDGMENTS}

Y. Liang is a recipient of a doctoral fellowship from China Scholarship Council (CSC, Beijing, China). F. Batistel was supported by a fellowship from Coordenação de Aperfeiçoamento de Pessoal de Nível Superior 
(CAPES, Brazilian Ministry of Education, Brasília, Brazil) and by Hatch funds under project ILLU-538914, National Institute of Food and Agriculture (Washington, DC).

\section{REFERENCES}

Abuelo, A., J. Hernandez, J. Benedito, and C. Castillo. 2013. Oxidative stress index $(\mathrm{OSi})$ as a new tool to assess redox status in dairy cattle during the transition period. Animal 7:1374-1378.

Ade, N., F. Leon, M. Pallardy, J.-L. Peiffer, S. Kerdine-Romer, M.-H. Tissier, P.-A. Bonnet, I. Fabre, and J.-C. Ourlin. 2009. HMOX1 and NQO1 genes are upregulated in response to contact sensitizers in dendritic cells and THP-1 cell line: Role of the Keap1/Nrf2 pathway. Toxicol. Sci. 107:451-460.

Aquilano, K., S. Baldelli, and M. R. Ciriolo. 2014. Glutathione: New roles in redox signaling for an old antioxidant. Front. Pharmacol. $5: 196$.

Batistel, F., J. Arroyo, A. Bellingeri, L. Wang, B. Saremi, C. Parys, E. Trevisi, F. Cardoso, and J. Loor. 2017. Ethyl-cellulose rumenprotected methionine enhances performance during the periparturient period and early lactation in Holstein dairy cows. J. Dairy Sci. 100:7455-7467.

Batistel, F., J. Arroyo, C. Garces, E. Trevisi, C. Parys, M. Ballou, F. Cardoso, and J. Loor. 2018. Ethyl-cellulose rumen-protected methionine alleviates inflammation and oxidative stress and improves neutrophil function during the periparturient period and early lactation in Holstein dairy cows. J. Dairy Sci. 101:480-490.

Bendich, A. 1993. Physiological role of antioxidants in the immune system. J. Dairy Sci. 76:2789-2794.

Bernabucci, U., B. Ronchi, N. Lacetera, and A. Nardone. 2005. Influence of body condition score on relationships between metabolic status and oxidative stress in periparturient dairy cows. J. Dairy Sci. 88:2017-2026.

Cardozo, L. F., L. M. Pedruzzi, P. Stenvinkel, M. B. Stockler-Pinto, J. B. Daleprane, M. Leite Jr., and D. Mafra. 2013. Nutritional strategies to modulate inflammation and oxidative stress pathways via activation of the master antioxidant switch Nrf2. Biochimie 95:1525-1533.

Contreras, G. A., C. Strieder-Barboza, and J. De Koster. 2018. Symposium review: Modulating adipose tissue lipolysis and remodeling to improve immune function during the transition period and early lactation of dairy cows. J. Dairy Sci. 101:2737-2752.

Contreras, G. A., C. Strieder-Barboza, J. De Souza, J. Gandy, V. Mavangira, A. L. Lock, and L. M. Sordillo. 2017. Periparturient lipolysis and oxylipid biosynthesis in bovine adipose tissues. PLoS One 12:e0188621.

Couto, N., J. Wood, and J. Barber. 2016. The role of glutathione reductase and related enzymes on cellular redox homoeostasis network. Free Radic. Biol. Med. 95:27-42.

Curtis, J. M., P. A. Grimsrud, W. S. Wright, X. Xu, R. E. Foncea, D. W. Graham, J. R. Brestoff, B. M. Wiczer, O. Ilkayeva, and K. Cianflone. 2010. Downregulation of adipose glutathione S-transferase A4 leads to increased protein carbonylation, oxidative stress, and mitochondrial dysfunction. Diabetes 59:1132-1142.

Du, X., T. Shen, H. Wang, X. Qin, D. Xing, Q. Ye, Z. Shi, Z. Fang, Y. Zhu, Y. Yang, Z. Peng, C. Zhao, B. Lv, X. Li, G. Liu, and X. Li. 2018. Adaptations of hepatic lipid metabolism and mitochondria in dairy cows with mild fatty liver. J. Dairy Sci. 101:9544-9558.

Du, X., Z. Shi, Z. Peng, C. Zhao, Y. Zhang, Z. Wang, X. Li, G. Liu, and X. Li. 2017. Acetoacetate induces hepatocytes apoptosis by the ROS-mediated MAPKs pathway in ketotic cows. J. Cell. Physiol. 232:3296-3308.

Fernández-Sánchez, A., E. Madrigal-Santillán, M. Bautista, J. Esquivel-Soto, Á. Morales-González, C. Esquivel-Chirino, I. DuranteMontiel, G. Sánchez-Rivera, C. Valadez-Vega, and J. A. MoralesGonzález. 2011. Inflammation, oxidative stress, and obesity. Int. J. Mol. Sci. 12:3117-3132.
Furukawa, S., T. Fujita, M. Shimabukuro, M. Iwaki, Y. Yamada, Y Nakajima, O. Nakayama, M. Makishima, M. Matsuda, and I. Shimomura. 2004. Increased oxidative stress in obesity and its impact on metabolic syndrome. J. Clin. Invest. 114:1752-1761.

Gessner, D. K., G. Schlegel, J. Keller, F. Schwarz, R. Ringseis, and K. Eder. 2013. Expression of target genes of nuclear factor E2-related factor 2 in the liver of dairy cows in the transition period and at different stages of lactation. J. Dairy Sci. 96:1038-1043.

Graff, E. C., H. Fang, D. Wanders, and R. L. Judd. 2016. Anti-inflammatory effects of the hydroxycarboxylic acid receptor 2. Metabolism 65:102-113.

Griffith, O. W. 1999. Biologic and pharmacologic regulation of mammalian glutathione synthesis. Free Radic. Biol. Med. 27:922-935.

Han, L., F. Batistel, Y. Ma, A. Alharthi, C. Parys, and J. Loor. 2018a. Methionine supply alters mammary gland antioxidant gene networks via phosphorylation of nuclear factor erythroid 2-like 2 (NFE2L2) protein in dairy cows during the periparturient period. J. Dairy Sci. 101:8505-8512.

Han, L. Q., Z. Zhou, Y. Ma, F. Batistel, J. Osorio, and J. J. Loor. 2018b. Phosphorylation of nuclear factor erythroid 2-like 2 (NFE2L2) in mammary tissue of Holstein cows during the periparturient period is associated with mRNA abundance of antioxidant gene networks. J. Dairy Sci. 101:6511-6522.

Ji, P., J. Osorio, J. Drackley, and J. Loor. 2012. Overfeeding a moderate energy diet prepartum does not impair bovine subcutaneous adipose tissue insulin signal transduction and induces marked changes in peripartal gene network expression. J. Dairy Sci. 95:4333-4351.

Kane, R. E., J. Tector, J. J. Brems, A. P. Li, and D. L. Kaminski. 1990. Sulfation and glucuronidation of acetaminophen by cultured hepatocytes replicating in vivo metabolism. ASAIO Trans. 36:M607-M610.

Kaspar, J. W., S. K. Niture, and A. K. Jaiswal. 2009. Nrf2: INrf2 (Keap1) signaling in oxidative stress. Free Radic. Biol. Med. 47:1304-1309.

Kensler, T. W., N. Wakabayashi, and S. Biswal. 2007. Cell survival responses to environmental stresses via the Keap1-Nrf2-ARE pathway. Annu. Rev. Pharmacol. Toxicol. 47:89-116.

Lee, Y.-J., H.-N. Cho, J.-W. Soh, G. J. Jhon, C.-K. Cho, H.-Y. Chung, S. Bae, S.-J. Lee, and Y.-S. Lee. 2003. Oxidative stress-induced apoptosis is mediated by ERK1/2 phosphorylation. Exp. Cell Res. 291:251-266.

Lee, Y. S., A. Y. Kim, J. W. Choi, M. Kim, S. Yasue, H. J. Son, H. Masuzaki, K. S. Park, and J. B. Kim. 2008. Dysregulation of adipose glutathione peroxidase 3 in obesity contributes to local and systemic oxidative stress. Mol. Endocrinol. 22:2176-2189.

Li, X., W. Huang, J. Gu, X. Du, L. Lei, X. Yuan, G. Sun, Z. Wang, X. Li, and G. Liu. 2015. SREBP-1c overactivates ROS-mediated hepatic NF- $\mathrm{B}$ inflammatory pathway in dairy cows with fatty liver. Cell. Signal. 27:2099-2109. https://doi.org/10.1016/j.cellsig .2015.07.011.

Loor, J. J. 2010. Genomics of metabolic adaptations in the peripartal cow. Animal 4:1110-1139.

Loor, J., G. Bertoni, A. Hosseini, J. Roche, and E. Trevisi. 2013a. Functional welfare - Using biochemical and molecular technologies to understand better the welfare state of peripartal dairy cattle. Anim. Prod. Sci. 53:931-953.

Loor, J. J., M. Bionaz, and J. K. Drackley. 2013b. Systems physiology in dairy cattle: Nutritional genomics and beyond. Annu. Rev Anim. Biosci. 1:365-392. https://doi.org/10.1146/annurev-animal $-031412-103728$.

Lu, S. C. 2009. Regulation of glutathione synthesis. Mol. Aspects Med. $30: 42-59$.

Martinov, M. V., V. Vitvitsky, R. Banerjee, and F. Ataullakhanov 2010. The logic of the hepatic methionine metabolic cycle. Biochim. Biophys. Acta 1804:89-96.

Mavangira, V., and L. M. Sordillo. 2018. Role of lipid mediators in the regulation of oxidative stress and inflammatory responses in dairy cattle. Res. Vet. Sci. 116:4-14.

McGown, C., A. Birerdinc, and Z. M. Younossi. 2014. Adipose tissue as an endocrine organ. Clin. Liver Dis. 18:41-58. 
Morey, S. D., L. Mamedova, D. Anderson, C. Armendariz, E. Titgemeyer, and B. Bradford. 2011. Effects of encapsulated niacin on metabolism and production of periparturient dairy cows. J. Dairy Sci. 94:5090-5104

Motohashi, H., and M. Yamamoto. 2004. Nrf2-Keap1 defines a physiologically important stress response mechanism. Trends Mol. Med. 10:549-557.

Murri, M., M. Insenser, M. Luque, F. J. Tinahones, and H. F. EscobarMorreale. 2014. Proteomic analysis of adipose tissue: Informing diabetes research. Expert Rev. Proteomics 11:491-502.

Nakashima, C., K. Yamamoto, R. Fujiwara-Tani, Y. Luo, S. Matsushima, K. Fujii, H. Ohmori, T. Sasahira, T. Sasaki, and Y. Kitadai. 2018. Expression of cytosolic malic enzyme (ME1) is associated with disease progression in human oral squamous cell carcinoma. Cancer Sci. 109:2036-2045.

Nguyen, T., P. Nioi, and C. B. Pickett. 2009. The Nrf2-antioxidant response element signaling pathway and its activation by oxidative stress. J. Biol. Chem. 284:13291-13295.

NRC. 2001. Nutrient Requirements of Dairy Cattle. 7th rev. ed. Natl. Acad. Press, Washington, DC.

Offermanns, S., S. L. Colletti, T. W. Lovenberg, G. Semple, A. Wise, and A. P. IJzerman. 2011. International Union of Basic and Clinical Pharmacology. LXXXII: Nomenclature and classification of hydroxy-carboxylic acid receptors (GPR81, GPR109A, and GPR109B). Pharmacol. Rev. 63:269-290.

Osorio, J. S., P. Ji, J. Drackley, D. Luchini, and J. Loor. 2013. Supplemental Smartamine M or MetaSmart during the transition period benefits postpartal cow performance and blood neutrophil function. J. Dairy Sci. 96:6248-6263.

Osorio, J. S., P. Ji, J. Drackley, D. Luchini, and J. Loor. 2014a. Smartamine M and MetaSmart supplementation during the peripartal period alter hepatic expression of gene networks in 1-carbon metabolism, inflammation, oxidative stress, and the growth hormone-insulin-like growth factor 1 axis pathways. J. Dairy Sci. 97:7451-7464.

Osorio, J. S., P. Ji, J. K. Drackley, D. Luchini, and J. J. Loor. 2014b. Smartamine M and MetaSmart supplementation during the peripartal period alter hepatic expression of gene networks in 1-carbon metabolism, inflammation, oxidative stress, and the growth hormone-insulin-like growth factor 1 axis pathways. J. Dairy Sci. 97:7451-7464.

Overton, T. R., D. W. LaCount, T. M. Cicela, and J. Clark. 1996. Evaluation of a ruminally protected methionine product for lactating dairy cows. J. Dairy Sci. 79:631-638.

Roche, J. R., A. W. Bell, T. R. Overton, and J. J. Loor. 2013. Nutritional management of the transition cow in the 21st century- $\mathrm{A}$ paradigm shift in thinking. Anim. Prod. Sci. 53:1000-1023. https: //doi.org/10.1071/AN12293.

Samland, A. K., and G. A. Sprenger. 2009. Transaldolase: From biochemistry to human disease. Int. J. Biochem. Cell Biol. 41:14821494.

Sena, L. A., and N. S. Chandel. 2012. Physiological roles of mitochondrial reactive oxygen species. Mol. Cell 48:158-167.

Shoelson, S. E., J. Lee, and A. B. Goldfine. 2006. Inflammation and insulin resistance. J. Clin. Invest. 116:1793-1801.

Spears, J. W. 2000. Micronutrients and immune function in cattle. Proc. Nutr. Soc. 59:587-594.

Stipanuk, M. H. 2004. Sulfur amino acid metabolism: Pathways for production and removal of homocysteine and cysteine. Annu. Rev. Nutr. 24:539-577.
Strange, R. C., M. A. Spiteri, S. Ramachandran, and A. A. Fryer. 2001. Glutathione-S-transferase family of enzymes. Mutat. Res. 482:21-26.

Titgemeyer, E. C., L. Mamedova, K. Spivey, J. Farney, and B. Bradford. 2011. An unusual distribution of the niacin receptor in cattle. J. Dairy Sci. 94:4962-4967.

Vailati-Riboni, M., G. Farina, F. Batistel, A. Heiser, M. Mitchell, M. Crookenden, C. Walker, J. Kay, S. Meier, and J. Roche. 2017. Far-off and close-up dry matter intake modulate indicators of immunometabolic adaptations to lactation in subcutaneous adipose tissue of pasture-based transition dairy cows. J. Dairy Sci. 100:2334-2350.

Vailati-Riboni, M., M. Kanwal, O. Bulgari, S. Meier, N. Priest, C. Burke, J. Kay, S. McDougall, M. Mitchell, and C. Walker. 2016. Body condition score and plane of nutrition prepartum affect adipose tissue transcriptome regulators of metabolism and inflammation in grazing dairy cows during the transition period. J. Dairy Sci. 99:758-770.

Vailati Riboni, M., S. Meier, N. Priest, C. Burke, J. Kay, S. McDougall, M. Mitchell, C. Walker, M. Crookenden, and A. Heiser. 2015. Adipose and liver gene expression profiles in response to treatment with a nonsteroidal antiinflammatory drug after calving in grazing dairy cows. J. Dairy Sci. 98:3079-3085.

Wen, D., D. Liu, J. Tang, L. Dong, Y. Liu, Z. Tao, J. Wan, D. Gao, L. Wang, and H. Sun. 2015. Malic enzyme 1 induces epithelial-mesenchymal transition and indicates poor prognosis in hepatocellular carcinoma. Tumour Biol. 36:6211-6221.

Yu, B. P. 1994. Cellular defenses against damage from reactive oxygen species. Physiol. Rev. 74:139-162

Yu, Y. P., G. Yu, G. Tseng, K. Cieply, J. Nelson, M. Defrances, R. Zarnegar, G. Michalopoulos, and J.-H. Luo. 2007. Glutathione peroxidase 3, deleted or methylated in prostate cancer, suppresses prostate cancer growth and metastasis. Cancer Res. 67:8043-8050.

Yuan, K., R. Shaver, S. Bertics, M. Espineira, and R. Grummer. 2012. Effect of rumen-protected niacin on lipid metabolism, oxidative stress, and performance of transition dairy cows. J. Dairy Sci. 95:2673-2679.

Zachut, M., G. Kra, L. Livshitz, Y. Portnick, S. Yakoby, G. Friedlander, and Y. Levin. 2017. Seasonal heat stress affects adipose tissue proteome toward enrichment of the Nrf2-mediated oxidative stress response in late-pregnant dairy cows. J. Proteomics 158:52-61.

Zhou, Z., O. Bulgari, M. Vailati-Riboni, E. Trevisi, M. A. Ballou, F. C. Cardoso, D. N. Luchini, and J. J. Loor. 2016a. Rumen-protected methionine compared with rumen-protected choline improves immunometabolic status in dairy cows during the peripartal period. J. Dairy Sci. 99:8956-8969. https://doi.org/10.3168/jds.2016 -10986 .

Zhou, Z., T. A. Garrow, X. Dong, D. N. Luchini, and J. J. Loor. 2017. Hepatic activity and transcription of betaine-homocysteine methyltransferase, methionine synthase, and cystathionine synthase in periparturient dairy cows are altered to different extents by supply of methionine and choline-3. J. Nutr. 147:11-19.

Zhou, Z., M. Vailati-Riboni, E. Trevisi, J. Drackley, D. Luchini, and J. Loor. 2016b. Better postpartal performance in dairy cows supplemented with rumen-protected methionine compared with choline during the peripartal period. J. Dairy Sci. 99:8716-8732.

Zhu, Y., G. Liu, X. Du, Z. Shi, M. Jin, X. Sha, X. Li, Z. Wang, and X. Li. 2018. Expression patterns of hepatic genes involved in lipid metabolism in cows with subclinical or clinical ketosis. J. Dairy Sci. 102:1725-1735. 